https://journal.uwgm.ac.id/index.php/abdimasmahakam

E-ISSN: 2549-5755

Januari 2020, Vol. 4 No. 01

Received: Juni 2019

Accepted: Oktober 2019

Published: Januari 2020

Article DOI: http://dx.doi.org/ 10.24903/jam.v4i1.542

\title{
Pengembangan Griya Anggrek Mekar Sari Kelurahan Kalisegoro Semarang
}

\author{
Noor Aini Habibah \\ Universitas Negeri Semarang \\ nooraini@mail.unnes.ac.id \\ Anindya Ardiansari \\ Universitas Negeri Semarang \\ anindya@mail.unnes.ac.id \\ Y. Ulung Anggraito \\ Universitas Negeri Semarang \\ y.ulung.anggraito@mail.unnes.ac.id
}

Fitri Arum Sari

Universitas Negeri Semarang

tredeef@yahoo.co.id

\begin{abstract}
Abstrak
Griya anggrek Mekar Sari merupakan rumah anggrek di wilayah Kalisegoro yang mempunyai potensi besar untuk berkembang. Tujuan pendirian Griya Anggrek Mekar Sari adalah meningkatkan keterampilan dan juga pendapatan Ibu-Ibu di wilayah RW 4 Kalisegoro Gunungpati Semarang. Tetapi sampai saat ini, 1 tahun setelah berdiri, tujuan tersebut belum tercapai. Berbagai penyebab telah diidentifikasi yaitu: penjualan yang rendah dan manajemen keuangan yang belum dilakukan. Tingkat penjualan yang rendah antara lain dipengaruhi terbatasnya koleksi anggrek, pemasaran yang hanya terbatas pada wilayah sekitar Kalisegoro, dan juga belum memadainya jumlah tenaga yang terampil memelihara anggrek serta sarana dan prasarana yang masih terbatas. Koleksi anggrek masih didominasi oleh jenis Dendrobium dengan keanekaragaman yang masih rendah. Terbatasnya jumlah tenaga terampil dalam budidaya anggrek menyebabkan kualitas anggrek yang ada juga tidak maksimal. Kurangnya sarana dan prasarana untuk budidaya anggrek juga menyebabkan kualitas anggrek sulit ditingkatkan. Belum dilaksanakannnya manajemen keungan juga menyebabkan rendahnya pendapatan. Dukungan untuk mengatasi hal tersebut perlu adanya peningkatan pengetahuan dan keterampilan yang berkaitan dengan pengelolaan Griya Anggrek Mekar Sari yaitu peningkatan pengetahuan dan keterampilan manajemen keuangan, budidaya anggrek, pemasaran anggrek serta penyediaan sarana dan prasarana yang memadai untuk budidaya anggrek. Terlaksananya manajemen keuangan yang baik, kualitas anggrek yang tinggi, koleksi anggrek yang beragam dan pemasaran anggrek yang luas telah meningkatkan penjualan. Koleksi anggrek meningkat hingga $98 \%$. Penjualan meningkat
\end{abstract}




\section{(A) ABDIMAS}

https://journal.uwgm.ac.id/index.php/abdimasmahakam

E-ISSN: 2549-5755

Januari 2020, Vol. 4 No. 01

hingga 81\%. Program pengembangan rumah anggrek Griya Anggrek Mekar Sari memberikan hasil yang positif.

Kata Kunci: Griya Anggrek Mekar Sari; Kalisegoro; pengelolaan manajemen keuangan; dan pemasaran anggrek.

\section{Pendahuluan}

Anggrek merupakan tanaman hias yang termasuk famili Orchidaceae. Anggota famili Orchidaceae ini dapat ditemukan di seluruh dunia, kecuali padang pasir yang kering dan daerah yang selalu tertutup salju. Jenis anggrek yang terdapat di dunia berkisar antara 17.00035.000. Kontribusi anggrek Indonesia dalam khasanah anggrek dunia cukup besar. Dari 20.000 spesies anggrek yang tersebar di seluruh dunia, 6.000 di antaranya berada di hutan Indonesia1 (Sandra 2002 dalam Sabran et al., 2003). Anggrek merupakan tanaman hias yang mempunyai nilai estetika tinggi. Bentuk dan warna bunga serta karakteristik lainnya yang unik menjadi daya tarik tersendiri dari spesies tanaman hias ini sehingga banyak diminati oleh konsumen, baik di dalam maupun luar negeri. Anggrek disukai sebagai bunga potong dan tanaman pot1 (Sabran et al., 2003). Tanaman anggrek selain sebagai tanaman hias karena memiliki bunga yang indah bentuk dan warnanya, juga bermanfaat sebagai ramuan obatobatan, bahan campuran minyak wangi atau minyak rambut 2 (Kartikaningrum et al., 2004). Berdasarkan pertumbuhannya, batang anggrek dapat dibagi menjadi dua golongan yaitu tipe simpodial dan tipe monopodial 3 (Darmonno, 2008).

Kelurahan Kalisegoro merupakan salah satu kelurahan di Kota Semarang, provinsi Jawa Tengah. Kelurahan ini masih berada di sekitar Universitas Negeri Semarang. Kelurahan Kalisegoro telah mencanangkan diri sebagai Kampung Sejuta Anggrek. Program ini didukung oleh pembuatan rumah anggrek di wilayah di Kelurahan Kalisegoro, salah satunya adalah Griya anggrek Mekar Sari yang berada di RW 4 Kalisegoro. Griya anggrek Mekar Sari dibangun atas prakarsa CSR Phapros pada tahun 2017. Rumah anggrek ini berupa green house berukuran $\pm 5,5 \times 3 \mathrm{~m} 2$ dan terletak di RT 1 RW 4 Kelurahan Kalisegoro. Bantuan yang telah diberikan adalah green house, pembuatan rak-rak dan juga tanaman anggrek Dendrobium beraneka warna dengan berbagai umur (Gambar 1). Bantuan Phapros ini disambut antuasias oleh masyarakat di RW 4 Kalisegoro dengan menyediakan lahan yang cukup luas untuk pembuatan green house di wilayah RT 1, dan juga mengadakan piket untuk penyiraman anggrek yang dibagi tiap RT (Gambar 2). Piket dilakukan tiap hari untuk menyiram anggrek terutama anggrek yang masih berukuran kecil. Selain itu juga dibentuk kepengurusan rumah anggrek yang diketuai oleh Ibu Hapsari dengan anggota seluruh ibu-ibu PKK RW 4 yang berjumlah sekitar 125 orang. Anggota aktif yang tergabung dalam kegiatan perawatan anggrek berjumlah 20 orang. 


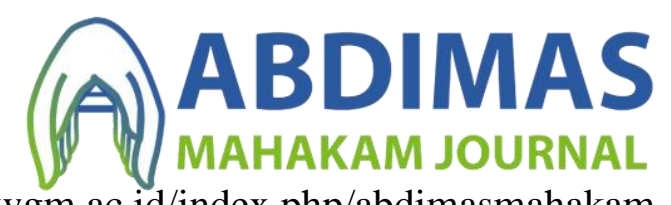

https://journal.uwgm.ac.id/index.php/abdimasmahakam

E-ISSN: 2549-5755

Januari 2020, Vol. 4 No. 01

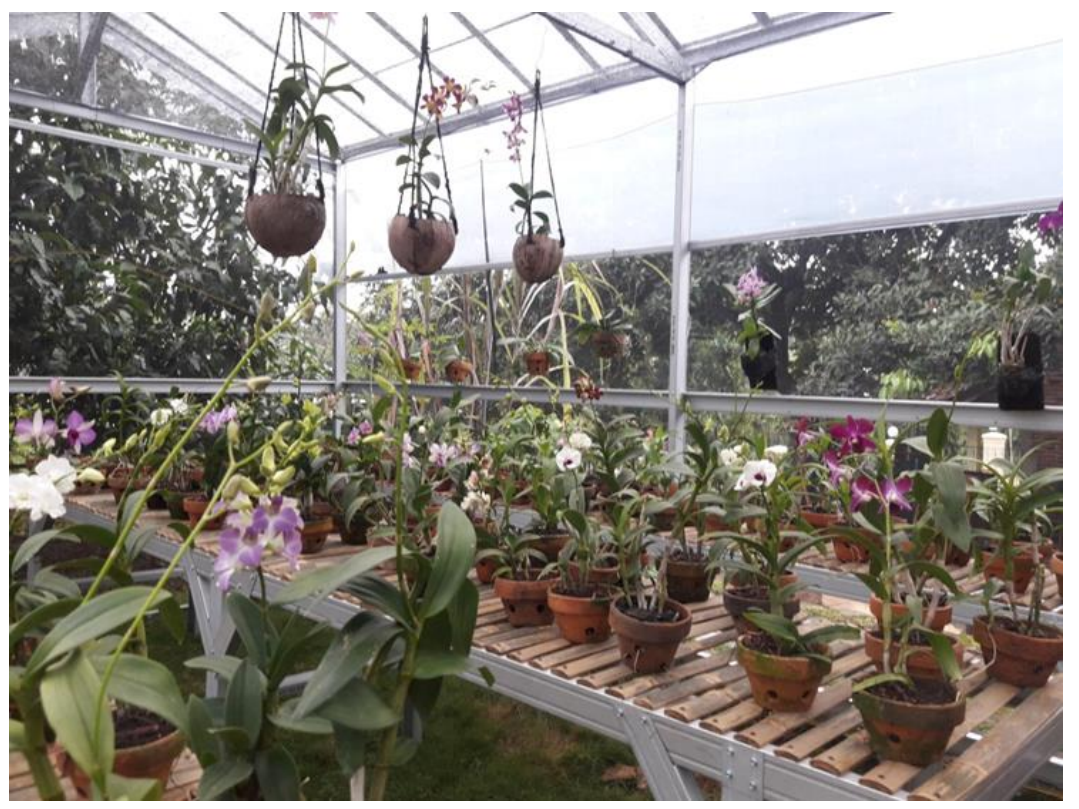

Gambar 1 Green House yang telah dibangun oleh Phapros
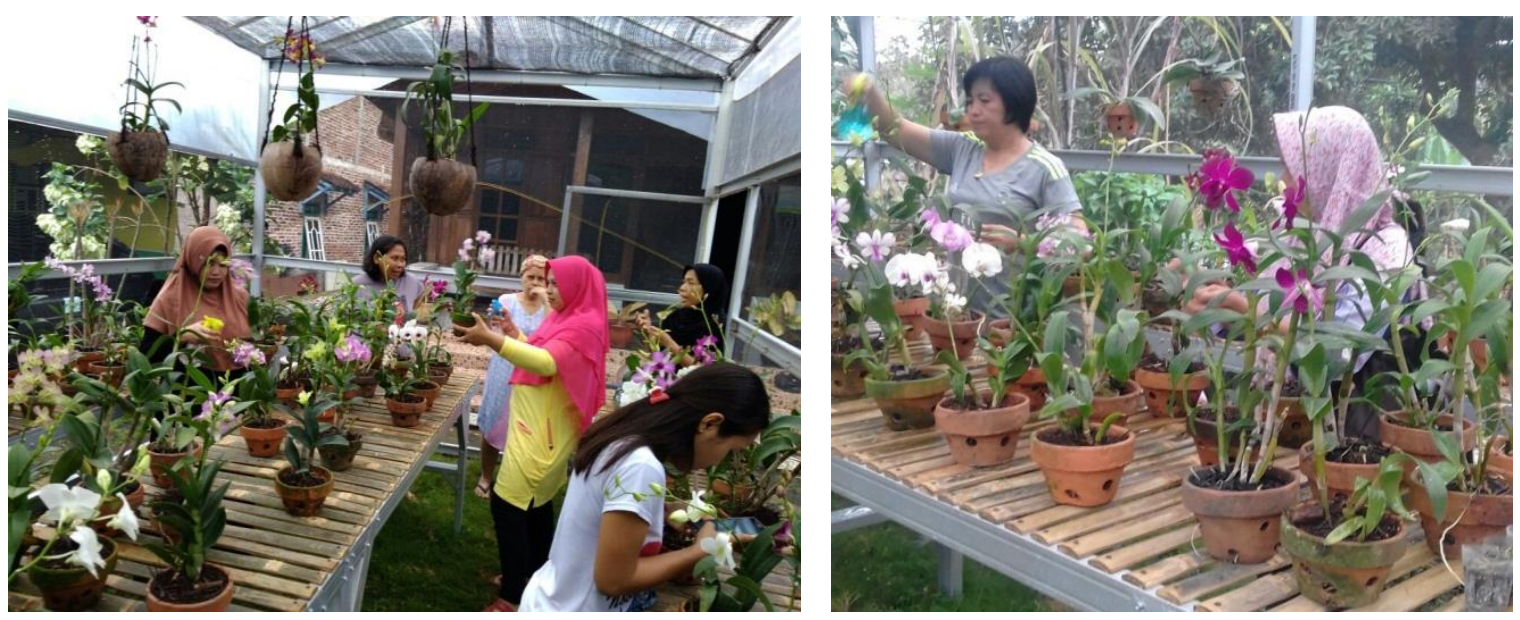

Gambar 2. Kegiatan piket yang diadakan oleh Ibu-ibu PKK RW 4

Griya Anggrek Mekar Sari didirikan dengan bantuan Phapros dengan tujuan akhir meningkatkan pendapatan warga di wilayah sekitar Griya Anggrek Mekar Sari. Tetapi tujuan ini sampai sekarang belum tercapai. Berbagai permasalahan yang menyebabkan tujuan tersebut belum tercapai antara lain tingkat penjualan yang rendah dan manajemen keungan yang belum tertata dengan baik. Selama waktu 8 bulan sejak Griya Anggrek Mekar Sari berdiri sampai saat ini hanya 49 tanaman yang terjual, atau 6 tanaman perbulan. Jumlah penjualan ini masih rendah dan belum memberikan dampak ekonomi yang berarti bagi anggota Griya Anggrek Mekar Sari. Tingkat penjualan yang rendah antara lain disebabkan karena koleksi anggrek yang masih terbatas. Koleksi yang ada saat ini didominasi anggrek Dendrobium. Koleksi anggrek yang lain masih sangat terbatas jumlahnya yaitu anggrek bulan dengan jumlah di bawah 10 tanaman. Sedangkan anggrek jenis lain belum tersedia. Koleksi 
Dendrobium yang ada juga mempunyai keanekeragaman yang tidak terlalu banyak. Beberapa pengunjung seringkali menanyakan anggrek jenis lain yang belum tersedia di Griya Anggrek Mekar Sari. Oleh karena itu maka perlu adanya penambahan koleksi anggrek sehingga menambah daya tarik pembeli. Tingkat penjualan yang rendah juga disebabkan karena kualitas anggrek yang masih rendah. Hal ini masih dapat dilihat bahwa sebagian tanaman terserang jamur sehingga daunnya berwarna kekuningan (Gambar 3). Perlu adanya peningkatan kualitas tanaman anggrek sehingga menarik pembeli. Selain itu pemeliharaan yang tidak maksimal menyebabkan anggrek yang dipelihara tidak sering berbunga. Padahal umumnya pembeli memilih anggrek yang telah berbunga untuk dibeli. Tingkat penjualan yang rendah juga disebabkan karena sarana dan prasarana yang masih terbatas. Sarana dan prasarana yang ada seperti gunting tanaman, wadah untuk pembibitan, sprayer, ember dan sebagainya masih menggunakan milik warga. Peralatan yang digunakan juga masih menggunakan peralatan seadanya. Padahal untuk pemeliharaan anggrek perlu alat yang memadai. Misalnya gunting yang digunakan adalah gunting tanaman dan harus disterilisasi dengan fungisida agar tidak menimbulkan adanya pertumbuhan jamur. Tingkat penjualan yang rendah juga disebabkan karena kurangnya strategi pemasaran. Saat ini pemasaran hanya dari sekitar wilayah Kalisegoro karena kurangnya publikasi. Perlu adanya strategi pemasaran yang lebih baik agar penjualan dapat meningkat. Permasalahan pemasaran telah dicoba untuk diatasi dengan pengembangan web Griya Mekar Sari, tetapi langkah ini masih belum memberikan hasil yang maksimal. Pengunjung web masih sangat jarang sehingga tidak memberikan dampak terhadap peningkatan penjualan. Tidak adanya manajemen kuangan yang baik juga menyebabkan rendahnya pendapatan yang diperoleh. Selama ini untuk menentukan harga jual anggrek hanya berdasarkan perkiraan saja, tanpa ada perhitungan modal dan laba. Bendahara hanya mencatat jumlah penjualan dan pembelian anggrek saja.

Pemeliharaan anggrek memerlukan peralatan dan ketrampilan khusus supaya dapat tumbuh dan berkembang dengan baik. Pertumbuhan tanaman anggrek di pengaruhi oleh beberapa faktor antara lain intensitas sinar matahari (intensitasnya,panjang hari atau jumlah penyinaran), kelembaban udara, dan temperature udara. Selain itu pertumbuhan anggrek juga dipengaruhi oleh medium pertumbuhan, air, makanan, dan faktor tambahan seperti hama dan penyakit4 (Sarwono, 2002). Persentase kebutuhan cahaya matahari untuk jenis anggrek berbeda-beda. Anggrek epifit umumnya membutuhkan intensitas cahaya matahari rendah yakni sekitar $25-50 \%$. Anggrek teresterial membutuhkannya cahaya matahari dalam jumlah lebih tinggi yakni sekitar 60 - 75\%5 (Iswanto, 2002). Nutrisi yang dibutuhkan anggrek antara lain adalah unsur-unsur karbon $(\mathrm{C})$, hidrogen $(\mathrm{H})$ dan oksigen $(\mathrm{O})$ yang berperan menyusun zat-zat makanan yang dibutuhkan oleh tumbuhan anggrek. Unsur-unsur esensial yang dibutuhkan oleh tumbuhan anggrek itu terdiri dari nitrogen $(\mathrm{N})$, fosfor $(\mathrm{P})$, kalium (K), magnesium (Mg) dan sulfur (S)6 (Gunawan, 2007).

Potensi rumah anggrek yang sangat besar ini perlu dikembangkan supaya memberikan manfaat yang besar bagi masyarakat di wilayah tersebut. Kegiatan inisiasi yang telah dilakukan oleh Phapros akan menjadi sia-sia tanpa adanya pendampingan untuk pengembangannya.

Mitra yang akan dilibatkan dalam kegiatan pengabdian kepada masyarakat ini adalah Griya Anggrek Mekar Sari. Griya Anggrek Mekar Sari saat ini telah dilengkapi dengan rak-rak dan tanaman anggrek jenis Dendrobium dan anggrek bulan. Namun demikian, karena masih belum adanya koleksi anggrek yang cukup beragam, belum adanya sumber daya 


\section{(A) ABDIMAS}

https://journal.uwgm.ac.id/index.php/abdimasmahakam

E-ISSN: 2549-5755

Januari 2020, Vol. 4 No. 01

manusia yang memahami manajemen keuangan, sumber daya manusia yang benarbenar terampil dalam pemeliharaan anggrek, sumber daya manusia yang terampil dalam pemasaran anggrek dan ketersediaan alat-alat pemeliharaan anggrek yang memadai maka peningkatan pendapatan belum bisa dirasakan oleh anggota Griya Mekar Sari.

\section{Metode}

Berdasarkan permasalahan yang ditemui di lapangan melalui hasil diskusi dengan mitra, maka atas kesepakan bersama antara mitra dan tim pengabdian ditentukan beberapa persoalan yang ditangani secara bersama-sama. Permasalahan yang diselesaikan adalah sebagai berikut: 1. Peningkatan koleksi anggrek. Koleksi anggrek yang perlu ditambahkan adalah Phaleonopsis (anggrek bulan), Vanda dan Catleya. Penambahan koleksi dilakukan dalam bentuk tanaman yang sudah berbunga dan bibit dalam botol.

2. Peningkatan pengetahuan dan keterampilan pemeliharaan anggrek melalui pelatihan bagi para pengelola Rumah anggrek Mekar Sari tentang materi pemeliharaan anggrek. Materi yang diberikan berkaitan dengan pemeliharaan harian yaitu cara dan waktu penyiraman yang tepat, dan pemeliharaan untuk induksi perbungaan serta pemberantasan hama dan penyakit. Selain itu juga diajarkan cara melakukan perbanyakan anggrek.

3. Peningkatan pengetahuan dan keterampilan manajemen keuangan dan pemasaran melalui pelatihan bagi para pengelola Rumah anggrek Mekar Sari tentang materi manajemen keuangan dan strategi pemasaran anggrek. Manajemen keuangan ditekankan pada bagaimana penentuan harga penjualan anggrek sehingga diperoleh laba yang menguntungkan.

4. Peningkatan sarana dan prasarana pemeliharaan anggrek. Berbagai peralatan yang diperlukan antara lain sprayer, pot, gunting tanaman, ember, kawat, rak pembibitan, pupuk, fungisida, lemari etalase untuk pupuk dan fungisida, moss, dan pakis disediakan agar pelaksanaan pemeliharaan anggrek menjadi lebih maksimal.

\section{Hasil dan Pembahasan}

Pengabdian telah dilaksanakan sesuai dengan rencana yang telah disusun. Pada tahap persiapan ini dilaksanakan koordinasi antar tim pengabdi dan juga koordinasi tim pengabdi dengan mitra. Koordinasi antar tim pengabdi berkaitan dengan materi yang harus disampaikan, metode penyampaian, tagihan yang harus dicapai dan juga persiapan pelaksanaan keseluruhan acara pengabdian. Hasil koordinasi antar tim pengabdi kemudian digunakan sebagai bahan untuk koordinasi dengan mitra. Pada saat koordinasi dengan mitra juga digunakan untuk menguatkan komitmen mitra untuk melaksanakan kegiatan pengabdian. Selain itu juga dilakukan penetapan jadwal-jadwal kegiatan yang telah disepakati.

Pada tahapan persiapan juga dilaksanakan persiapan untuk pembelian anggrek dengan mengunjungi beberapa sentra anggrek untuk melihat koleksi anggrek yang ada. Sentra anggrek yang dikunjungi adalah kebun anggrek di daerah Mijen, Salatiga dan Magelang (Gambar 3 dan Gambar 4). Hal ini bertujuan untuk mendapatkan kaoleksi anggrek yang beranekaragam. Umumnya setiap sentra anggrek terbatas jenis anggreknya, untuk itu maka perlu dilakukan pembelian dari beberapa sentra anggrek. Selain itu juga dilakukan persiapan bahan dan tempat untuk pelatihan anggrek. 


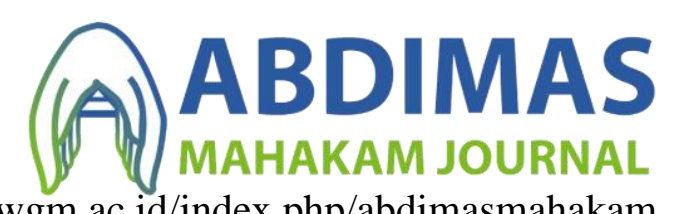

https://journal.uwgm.ac.id/index.php/abdimasmahakam

E-ISSN: 2549-5755

Januari 2020, Vol. 4 No. 01
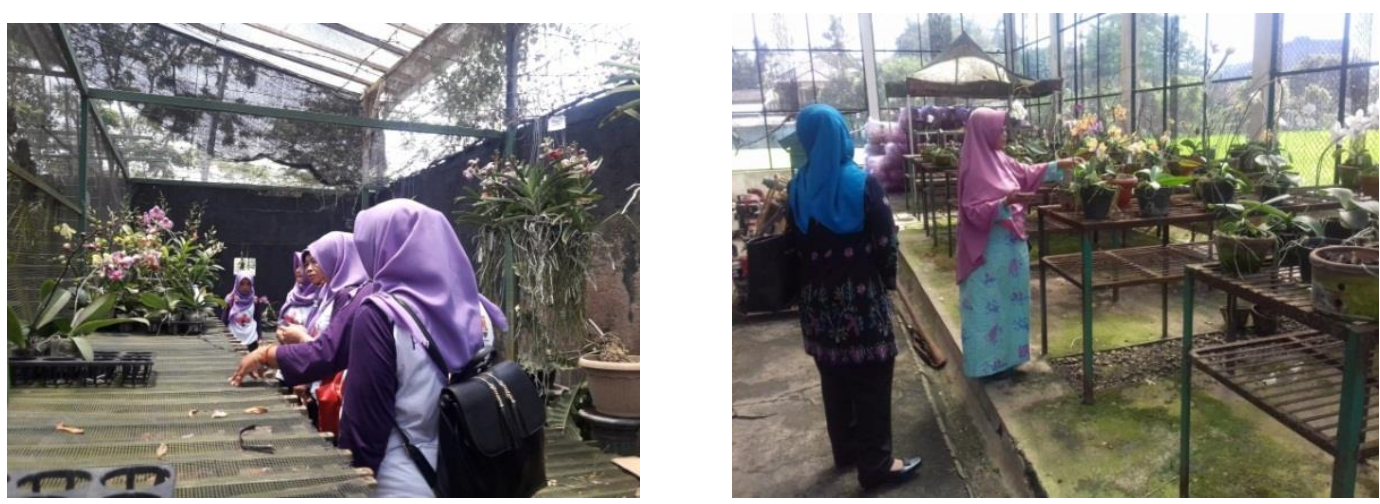

Gambar 3. Kunjungan ke sentra anggrek Nambangan Magelang

\section{Pelatihan}

Pelatihan dilaksanakan 2 kali yaitu pelatihan pertama adalah pelatihan pemeliharaan dan budidaya anggrek yang akan diberikan oleh anggota tim pengabdian yaitu Dr. Noor Aini Habibah dan Dr. Ulung Anggraito (Gambar 5 dan Gambar 6). Selain itu juga diundang praktisi anggrek Ibu Rumit Widyaningsih.

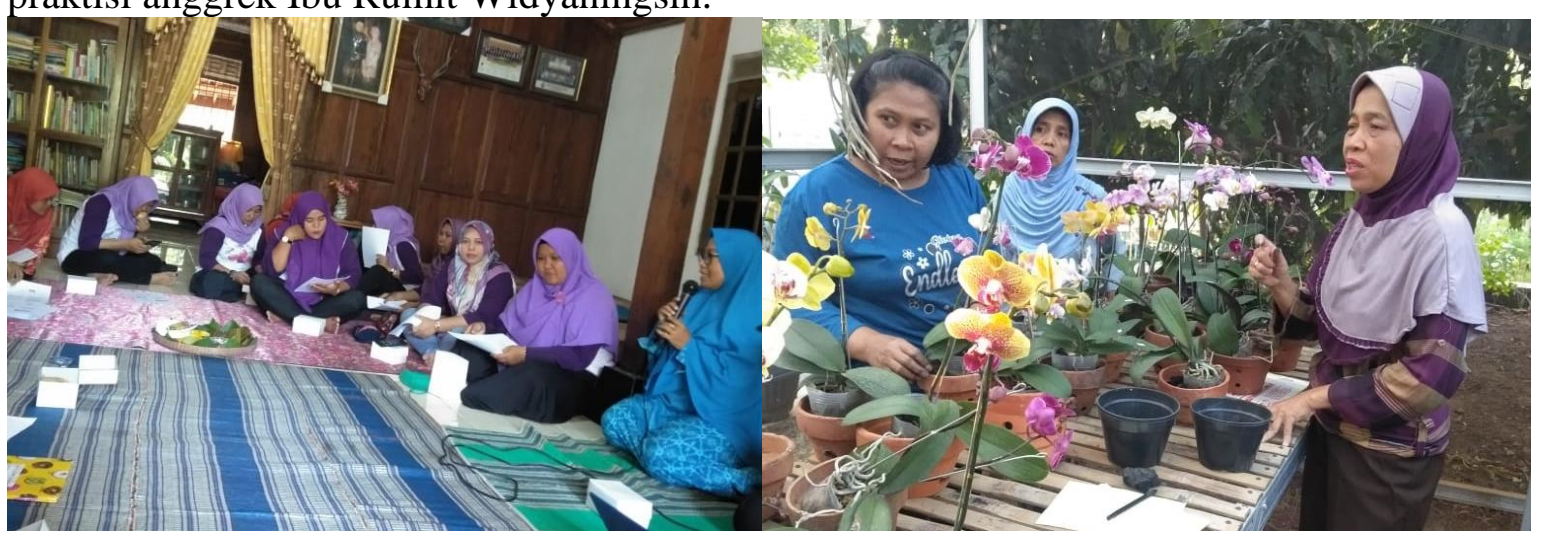

Gambar 5. Materi Pemeliharaan anggrek

Gambar 6. Praktek di green house anggrek

Pelatihan kedua adalah pelatihan manajemen keuangan dan strategi pemasaran anggrek, yang akan diberikan oleh tim pengabdi yang merupakan pakar ekonomi yaitu Dr. Anindya. Materi yang diberikan antara lain perhitungan laba, rugi dan penetapan harga jual. Pelatihan diikuti oleh anggota Griya anggrek Mekar Sari secara penuh.

Pembuatan buku saku pemeliharaan anggrek dan leaflet pemasaran anggrek

Pembuatan buku saku dilakukan oleh tim pengabdi yaitu Dr. Noor Aini Habibah, M.Si dan Dr. Y. Ulung Anggraito, M.Si. Praktisi anggrek Ibu Rumit Widyaningsih juga memberikan tambahan materi dalam buku saku pemeliharaan anggrek. Buku saku ini digunakan sebagai pegangan untuk anggota Griya Anggrek Mekar Sari dalam pemeliharaan anggrek. Selain itu buku saku ini juga dapat diperjualbelikan untuk para konsumen pembeli anggrek. Buku saku berisi karakteristik anggrek dan panduan pemeliharaan 4 jenis anggrek yaitu Dendrobium, Anggrek bulan, Vanda dan Catleya. Empat jenis anggrek ini merupakan anggrek yang umum dibudidayakan oleh masyarakat. 
https://journal.uwgm.ac.id/index.php/abdimasmahakam

E-ISSN: 2549-5755

Januari 2020, Vol. 4 No. 01

Salah satu strategi pemasaran yang dilakukan adalah pembuatan leaflet. Leaflet ini disebarluaskan pada saat bazar, kepada tamu ataupun pembeli. Leaflet ini berisi informasi Griya anggrek Mekar Sari meliputi: alamat, kontak, peta, koleksi anggrek dan keunggulan rumah anggrek Mekar Sari (Gambar 7).

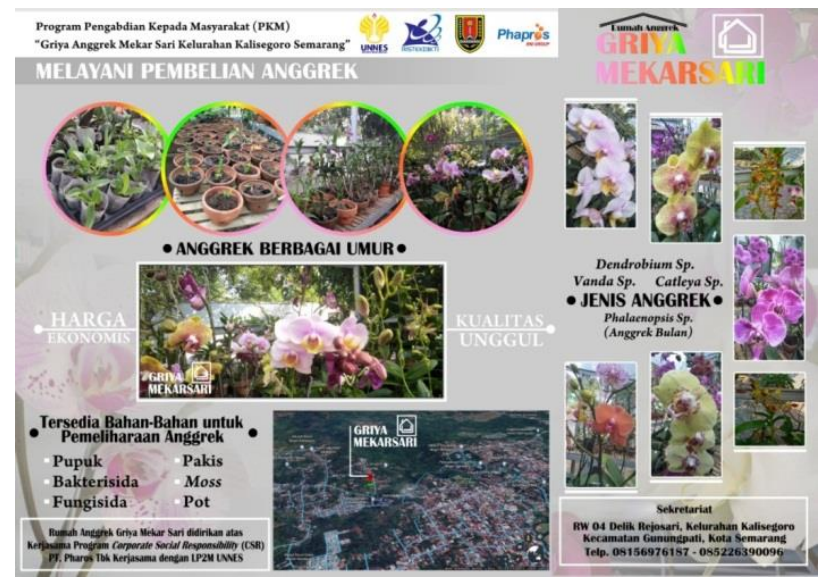

Gambar 7. Desain leaflet untuk pemasaran anggrek Griya Mekar sari

Penambahan koleksi anggrek

Salah satu strategi pemasaran untuk meningkatkan penjualan anggrek di Griya Anggrek Mekar sari adalah penambahan koleksi anggrek. Koleksi anggrek yang mulanya hanya didominasi anggrek Dendrobium dan sedikit varian anggrek Bulan, ditambah dengan anggrek Vanda dan catleya. Selain itu varian anggrek Dendrobium juga ditambah antara lain dengan menambah varian anggrek Dendrobium keriting yang saat ini cukup digemari. Varian anggrek bulan yang beraneka warna dan motif juga ditambahkan untuk menarik para pembeli. Selain itu anggrek yang masih kecil juga ditambah jumlahnya untuk menjamin persediaan tanaman yang kontinyu. Anggrek yang masih kecil secara kontinyu di pupuk agar tumbuh maksimal dan dapat berbunga.

Selain penambahan koleksi tanaman anggrek, dilakukan juga penambahan sarana pemeliharaan anggrek. Tim pengabdi juga menyerahkan kepada Griya Anggrek Mekar Sari bahan-bahan yang diperlukan untuk pemeliharaan anggrek, seperti fungisida, bakterisida, pupuk dan media tanam. Selain itu juga disediakan alat yang diperlukan seperti pot, gunting, dan juga sprayer. Penambahan alat dan bahan ini selain untuk memenuhi kebutuhan dalam pemeliharaan anggrek di Griya Mekar sari, tetapi juga untuk diperjualbelikan. Penyediaan bahan-bahan ini bertujuan untuk semakin menarik pembeli, sehingga pembeli tidak lagi bersusah payah mencari berbagai keperluan anggrek di tempat lain, tetapi semua sudah tersedia di rumah anggrek Griya Mekar Sari.

\section{Monitoring dan Evaluasi}

Peserta sangat antusias ditunjukkan dengan pertanyaan yang muncul dari para peserta dan juga melaksanakan praktek yang berkaitan dengan perbanyakan anggrek. Pada akhir sesi pelatihan dilakukan sesi quiz yang diberikan kepada Ibu-Ibu dengan hadiah tanaman anggrek. Pertanyaan quiz didasarkan pada materi yang diberikan saat pelatihan. Sesi quiz ini berjalan dengan sangat menarik karena peserta berebut menjawab pertanyaan untuk mendapatkan 
https://journal.uwgm.ac.id/index.php/abdimasmahakam

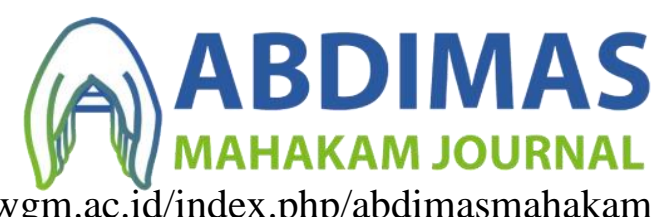

E-ISSN: 2549-5755

Januari 2020, Vol. 4 No. 01

hadiah tanaman anggrek. Sepuluh tanaman anggrek dibagikan untuk 10 peserta yang dapat menjawab pertanyaan. Hasil qiuz menunjukan bahwa peserta mampu menyerap ilmu yang telah diberikan. Selain itu keberhasilan pelatihan juga ditunjukan dengan adanya salah satu anggota Griya Anggrek mekar Sari yang ditunjuk oleh Dinas Pendidikan untuk memberikan materi pemeliharaan anggrek pada Ibu-Ibu Darma wanita.

Penambahan koleksi anggrek juga sangat tinggi hingga mencapai 98\% (Gambar 8). Koleksi ini meliputi 4 jenis anggrek yaitu anggrek bulan, anggrek Dendrobium, anggrek Vanda dan Anggrek Catleya.

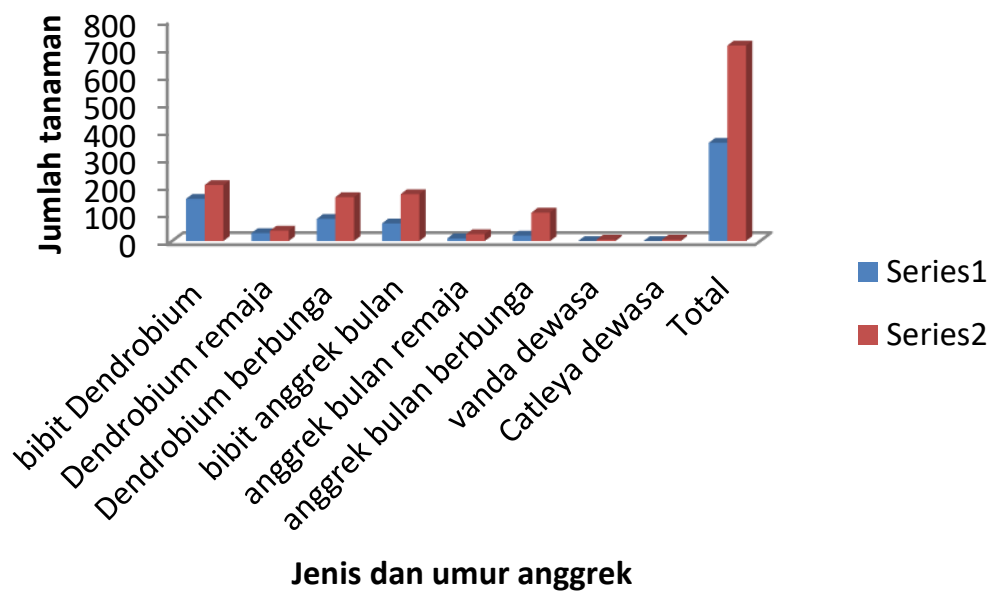

Gambar 8. Penambahan Koleksi Anggrek

Penambahan koleksi anggrek mendorong terjadinya peningkatan penjulan anggrek. Penjualan anggrek yang tinggi terjadi pada bulan Juni dan Juli 2019 (Gambar 9). Jumlah penjualan tahun 2019 meningkat $81 \%$ dari tahun 2018.

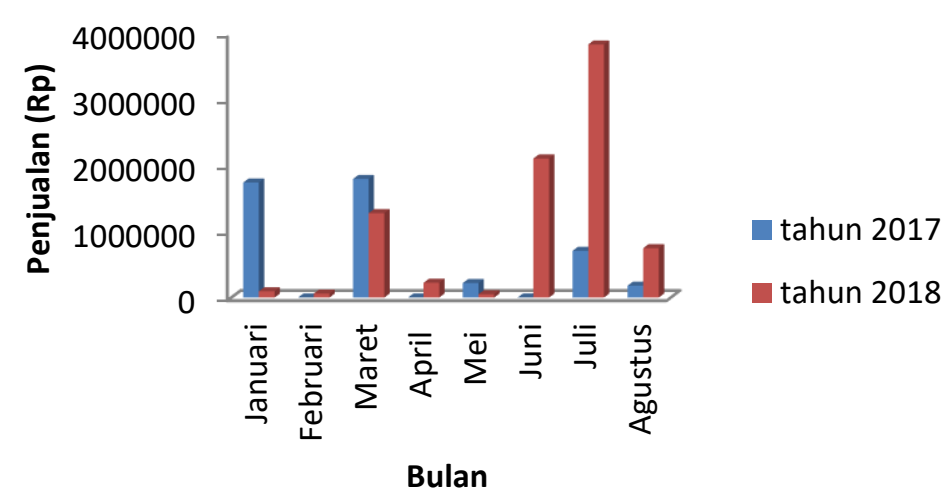

Gambar 9. Penjualan Anggrek tiap bulan di Griya Anggrek Mekar Sari 
https://journal.uwgm.ac.id/index.php/abdimasmahakam

E-ISSN: 2549-5755

Januari 2020, Vol. 4 No. 01

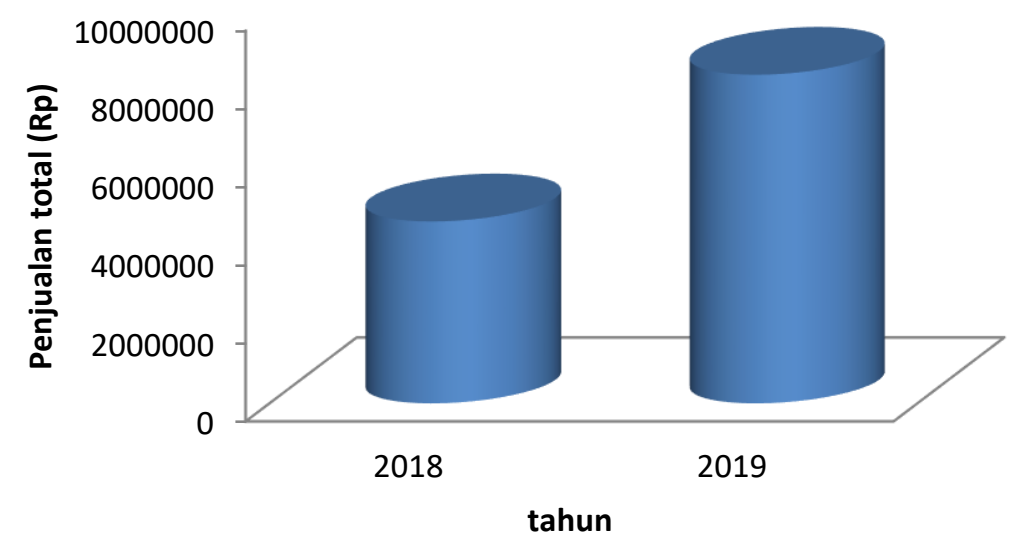

Gambar 10. Penjualan Total Anggrek di Griya Anggrek Mekar Sari

\section{Simpulan dan rekomendasi}

Pengembangan rumah anggrek Griya Mekar Sari dengan peningkatan ketrampilan dalam budidaya, manajemen, peningkatan koleksi anggrek dan prasarana pemeliharaan anggrek memberikan dampak yang positif terhadap penjualan anggrek hingga mencapai $81 \%$. 


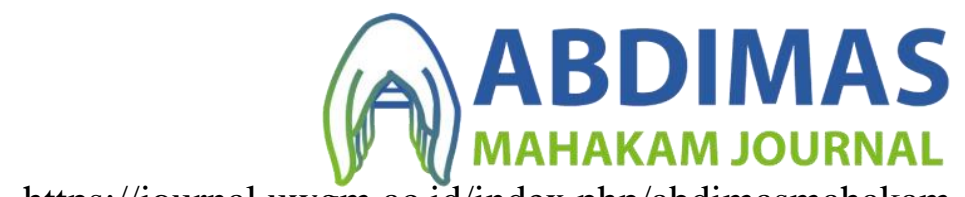

https://journal.uwgm.ac.id/index.php/abdimasmahakam

E-ISSN: 2549-5755

Januari 2020, Vol. 4 No. 01

\section{Daftar Pustaka}

Sabran M., A. Krismawati, Y.R. Galingging, dan M.A. Firmansyah. 2003. Eksplorasi dan Karakterisasi Tanaman Anggrek di Kalimantan Tengah. Buletin Plasma Nutfah Vol.9 No.1: 1-6.

Kartikaningrum, S, Dyah widastoety \& Kusumah. 2004. Panduan Karakterisasi TanamanAnggrek. Badan penelitian dan pengembangan pertanian komisi nasional platma.

Darmono, D. W. 2008. Agar Anggrek Rajin Berbunga. Jakarta: Penebar Swadaya.

Sarwono, B. 2002. Mengenal dan membuat anggrek hibrida. Agromedia. Jakarta

Iswanto, H. 2002. Petunjuk Perawatan Anggrek. Angromedia. Jakarta.

Gunawan, L. W. 2007. Budidaya Anggrek. Edisi Revisi. Jakarta: Penebar Swadaya. 